\title{
THIRTY-SIXTH ANNUAL REPORT OF THE STATE GEOLOGIST
}

\author{
Iowa Geologrcal Survey, \\ Des Moines, December 31, 1927. \\ To Governor John Hammill and Members of the Geological \\ Board:
}

Gentlemen: The most important resource of all the natural resources of Iowa is water. Knowledge of this fact has stimulated the Iowa Geological Survey, ever since it was organized in 1892, to investigate thoroughly this great asset of the state. For more than thirty years Professor William H. Norton has been in charge of studies pertaining to the quantity, quality, conditions of occurrence, and other features of our underground waters. As a result of the work done by Doctor Norton and his assistants, the Survey has been able to furnish much valuable information to the people of the state regarding our water supply. The most comprehensive report which has been published is Volume XXI of the Reports of the Survey. This volume, which was prepared in coöperation with the United States Geological Survey, is entitled Underground Water Resources of Iowa. In the Introduction to this Report Doctor Norton stated:

"The need of the scientific investigation of artesian waters is obvious to all. Many of these deep zones of flow lie far below the surface and below the sources that supply the common wells. The local well driller can not be expected to know either the quantity or the quality of artesian waters or the depth at which they can be reached. Town councils in considering municipal supply often send committees to the nearest towns which have deep wells to obtain such facts as may throw light upon the local problem. Information thus gathered may be useful or it may be misleading; it is always insufficient and inconclusive. There is needed the skillful interpretation of data collected from a wide area, a knowledge of the geologic structure and acquaintance with the distribution and movements of deep waters. For house wells in towns, and for common farm 
wells, the knowledge of local conditions held by the well drillers of the district is ordinarily sufficient. Yet even here a scientific knowledge of general as well as local conditions often makes it possible to suggest new and better sources of ground water or new and better methods of utilizing those now in use.

The object of the investigation, whose results are here presented, is to furnish to each community so far as possible deductions made from the entire body of facts obtainable, showing whether artesian water can be found at that locality, at what depths it may be reached, through what formations the drill must pass, what mineral compounds-healthful or harmful-the water is likely to contain, how high it will rise, how large will be its discharge, and how such a supply will compare in cost, purity, permanence, and general availability with that from other sources."

It was in 1912 that Volume XXI.was published. The information it contains has been and will continue to be of great service to all persons interested in underground waters. Since the publication of this volume, more than fifteen years ago, many deep wells have been drilled in different parts of the state, in connection with which many additional data have been secured by Doctor Norton and other persons connected with the Survey. In order that this information may be available to the citizens of Iowa Doctor Norton has prepared a supplement to his former report. The title of the supplement is Deep Wells of Iowa. This splendid paper, accompanied by a short paper by Doctor James H. Lees, Assistant State Geologist, on Well Water Recessions in Iowa, is herewith submitted to the Board with the recommendation that both papers be published as Volume XXXIII-the Thirty-Sixth Annual Report of the Iowa Geological Survey.

Advance figures for the output of mineral products in Iowa in 1927 indicate that amounts and values are about as follows:

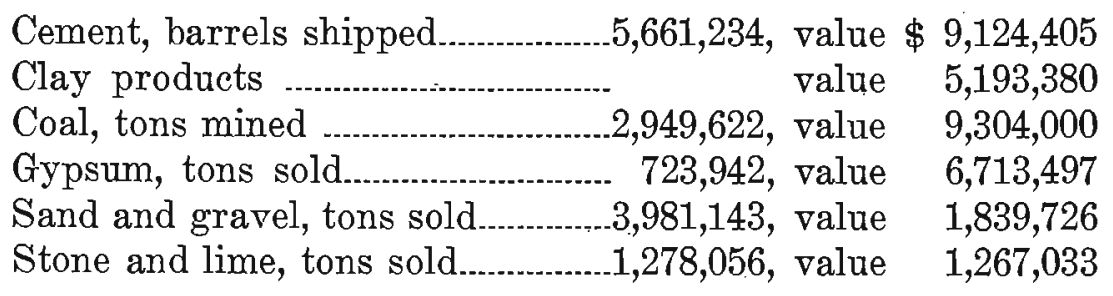


This is a decrease from the production of the previous year of $\$ 2,543,738$.

Respectfully submitted,

GEORGe F. Kay, State Geologist. 
